\title{
THE COMMUNICATION STRATEGIES ON TOURIST GUIDE PROFESSIONALISM IN LOMBOK WEST NUSA TENGGARA
}

\author{
${ }^{1}$ Ahmad Hanan \& ${ }^{\mathbf{1}}$ Sugianto \\ ${ }^{1}$ English Lecturer, FBMB, Mandalika University of Education, Indonesia \\ Corresponding Author Email: ahmadhanan@undikma.ac.id
}

\begin{tabular}{ll}
\hline \hline Article Info & Abstract \\
\hline Article History & This study was aimed at finding out the communication strategies on tourist \\
Received: June 2021 & guide professionalism in Lombok West Nusa Tenggara. The main research \\
Revised: July 2021 & question raised in the study was "How the communication strategies were used \\
Published: July 2021 & by the tour guides in terms of being professional tourists guides ". The research \\
\hline Keywords & was categorized into a descriptive qualitative study where the researcher used \\
Communication strategy; & purposive sampling with a specific subset of people to find out the exact criteria \\
Tourist guides; & of respondents. The researcher adopted snowball techniques in describing and \\
Professionalism; & interpreting the role of self-presentation on tourist guide professionalism. There \\
& were five tourist guides on the bus tour in their videos recorder and \\
& questionnaires towards communication strategies of English speech manner \\
& regarding tourist guides' professionalism. The sample was purposively taken by \\
involving the guided cruise ship passenger tour at Lembar harbor. The result of \\
the study found that the tourist guide's professionalism with the role of self- \\
presentation was positively related with the categories of self-promotion, \\
Ingratiation, supplication, exemplification, and Intimidation. Further, it was \\
found as well that the tourist guides professionalism performances were \\
positively related to the role of communication strategies under five main \\
categories. The study concluded that five communication strategies were used by \\
the tourist guide those are (1) Paraphrase with various Subcategories \\
Approximation, Word Coinage, and Circumlocution (2). Transfer with two \\
elements: (a) Literal Translation (b) Language Switch (3). Appeal for Assistance. \\
(4). Mime (5). Avoidance Strategy consists of two subcategories (a) Topic \\
Avoidance and (b) Message Abandonment.
\end{tabular}

How to site: Hanan, A. \& Sugianto. (2021). The communication strategies on tourist guide professionalism in Lombok, West Nusa Tenggara. JOLLT Journal of Languages and Language Teaching, 9(3) DOI: https://doi.org/10.33394/jollt.v\%vi\%i.3880

\section{INTRODUCTION}

This study was conducted mainly for the sake of investigating the communication strategies used by the professional tourist guides in Lombok. These communication strategies are vital in relation to the visitors, the area, and its people. Through the study, the researcher attempted to find out some research questions aimed at clarifying the role of self-presentation strategy observation, referring to the tourist guides' self-presentation in Lombok, it deals with the type of selves tourist guides presentation.

One of the communication strategies, well known as self-presentation, is conveying information about oneself or an image of oneself to others. There are two types and motivations of self-presentation: (1) presentation meant to match one's own self-image, and (2) presentation meant to match audience expectations and preferences. Through various selfpresentation activities, tourists may have a chance to reflect on their travels, share their own experiences, and form their sense of self through social support. As well, the theoretical accounts of self-presentation which is said as presented Ingratiation as a form of impression management by which actors can elicit positive responses from others (Huang. 2009: 27) 
By and large, the tour guiding is understood as a profession where a tour guiding (interpretation) is trying to produce mindful visitors; visitors who are active, questioning, and capable of reassessing the way they view the world". Moreover, dealing with the profession of a tour guide, it is identified that there are three primary ways in which tourist guides can help tourist enhance the quality of their experience. Firstly, providing information on available options. Secondly, providing information to encourage safety and comfort and the third is by creating the actual experience. Because of the tourist guides with their professionals performing a communicative function, which involves transferring information where to look, what to look for, and when to look, towards an encouragement to look with interest at an enormous diversity of cultures.

Here in this research, The researcher focused on the role of tourist guides to using the criteria for communication strategies in terms of being professional tourists guides. There are three criteria that must be present in a communication strategy: Firstly, A speaker desires to communicate meaning to a listener. Secondly, the speaker believes the linguistic or sociolinguistic structure desired to communicate meaning is unavailable or is not shared with the listener. The speaker chooses to avoid/ abandon his attempt to communicate meaning, to attempt alternative means to communicate meaning. And the third is that the speaker stops trying alternatives when it seems clear to him that there is shared meaning.

Likewise, the guides should have their communication strategies criteria as Rabotić (2009) proposed five criteria to identify communication strategies: the first is noticeable deviance from native speaker norm in the first language syntax or word choice or discourse pattern. The second is Apparent, obvious desire on the part of the speaker to communicate "meaning" to listeners as indicated by overt and covert discourse clues. The third is Evident and sometimes repetitive attempts to seek alternative ways, including repairs and appeals, to communicate and negotiate meaning. The fourth is Overt tautological, hesitation and other temporal features in the speaker's communicative behavior. The fifth is Presence of paralinguistic and kinesthetic features in support of linguistic inadequacy.

The role of the tourist guide as Rabotic (2009:67) implies that tourist guides are primarily information providers being particularly important at the beginning of tourists' stay at a destination. Further, it is said as well that the role of the tourists' guide are complex and diverse, consisting of numerous sub-roles. They had been: information provider, social facilitator, cultural host, motivator of conservation values, interpreter of the natural and cultural environment, people mover".

What guides should be expected to do in terms of facing real challenges stakeholders' expectations by tourist guides is to become a professional one. Ham (2002) claims Professionals are similar to mentors. Still, while the original role of the mentor was spiritual and intellectual guidance, the communicative function of the professional/ mentor tour guide has four components: the first is a selection of the itinerary ( what to see and experience- also what not to see); the second is dissemination of correct and precise information; the thirth is interpretation of what is seen and experienced and the fourth fabrication, that is, presenting fake information as though it were genuine/ true.

A tourist guide plays an important role in tourism. Pond (2009) suggests that a tourist guide is one who is a leader capable of assuming responsibility (leader). While, Weiler and Ham, (2002) maintain tourist guides have a number of responsibilities as providers of tourism experiences, with sometimes competing roles in order to meet the needs of visitors, employers and host communities. So that, being tourist guides are required special skills that include language skills, guiding techniques and insights extensive knowledge. Tourist could have a good experience of all elements of destination performing as desired and tourist guide providing the necessary connect. Tourist guides are responsible for tourist satisfaction with services provided in destinations. 
Dealing with how a tourist guide' roles Moscardo (2008) identifies three primary ways in which tourist guides can help tourists enhance the quality of their experience the first is by providing information on available options the second is by providing information to encourage safety and comfort and the thith is by creating the actual experience. Selfpresentation is the process by which individuals represent themselves to the social world. This process occurs at both conscious and unconscious (automatic) levels and is usually motivated by a desire to please others and/or meet the needs of the self.

Barkers, Alan (2010:12) define communication is the act of transmitting and receiving information. And the term communication strategy may occur in either pseudo communication or real-life communication both inside and outside language. For this present study refers to knowledge or ability used by tourist guide professionalism in Lombok.

\section{RESEARCH METHOD}

The qualitative research method was used in this study to define the anwer of the research question that questioning how is the communication strategies used by the tour guides as part of their professionalism in helping and satisfying the visitors of a particular destination area. The qualitative data was collected and analyzed to draw some conclusions of the study conducted.

Dealing with qualitative research, Kaplan and Maxwell (2010) point out, the goal of qualitative research is to understand a phenomenon from the point of view of the participants and its particular social and institutional collected text, which might be lost when textual data is quantified. Qualitative researchers view reality as socially constructed and seek to describe and interpret the meanings people attribute to situations. The qualitative research approach is active and dynamic and continually evolving as research questions are embryonic in the light of respondents' conceptualizations of reality and based on emerging insights in the data collection process.

\section{Research Design}

The researcher applied a descriptive qualitative research design in this study since the researcher wanted to describe how the language used in the Role of Self Presentation and Communication Strategies on Tourist Guides Professionalism of Tourist Guide in Lombok in the real situation. The researcher assumes that by using this method it could get the authentic and objective data. The rich natural data that were collected gave incredible insight to answer the research questions of the study. The researcher gets involve in social life of the tour guiding in Lombok.

Moreover location of this study is familiar to the researcher, thus it was easier for the researcher to make an approach with the tour guides that in charge for the guided tour cruise ship passenger at Lembar harbor, especially with subjects (the tourist guides). When the subjects have a good relation with the researcher, then they are not aware that they are being observed. It is really important because most of the data will be found from the communication. Thus, when they communicate with passengers on tour packages being offered by the cruise director, they talk as natural without any feeling of worrying.

\section{Subject}

This study involved Lombok tourist guides that in charge for the guided cruise ship passenger tour at Lembar harbor. It was carried out from September to October 2015. It revealed that the taxonomy of self presentation and Communication Strategy that they are considered as the most recently established ones, included the ability to cope with oral communication due to inadequate linguistic knowledge and socio-cultural knowledge and the ability of individuals to express concerns regarding access to guide's professionalism. 
The sampling technique that the researcher used "Purposive sampling", As it is stated by Mack. N and Woodsong C, (2005:5): "one of the most common sampling strategies, group's participants according to preselected criteria relevant to a particular research question. Sample sizes, which may or may not be fixed prior to data collection, depend on the resources and time available, as well as the study's objectives. Purposive sample sizes are often determined on the basis of theoretical saturation (the point in data collection when new data no longer bring additional insights to the research questions). Purposive sampling is, therefore most successful when data review and analysis are done in conjunction with data collection. Purposive sampling is when a researcher targeted a specific subset of people who meet the exact criteria of respondents or target group. Snowball techniques were used; that is, respondents recommended their Video and tape recorder to the researcher and assisted the researcher in describing and interpret the type of self-presentation and Pre-coding reflections (noting down the researcher thoughts in memos shape) for communication strategies on tourist guides professionalism.

\section{Instrument}

Video recording was the first research instrument used in this study. It was used to record the whole self-presentation on five tourist guide's professionalism at leading others to believe one possess various characteristics. The second research instrument used in this study is field note. The field note was used to document the communication strategies of tourist guides' professionalism.

Collecting data is one of the important steps in conducting research because the data had been needed. Therefore the data should be collected accurately by using an appropriate technique. Record Video shooting for the role of self-presentation on five tourist guide's professionalism at leading others to believe ones possess various characteristics Note down the researcher thoughts in memos shape for communication strategies on tourist guides professionalism in term of reflecting five tourist guides, at leading others to believe ones possess various characteristics.

\section{Data Analysis}

Analyzing the data in this study, the researcher investigated the subjects of this study who get in charge of that particular guided tour. The researcher was not only watching them but also recorded every situation of their self-presentation and pre-coding reflection communication strategies in terms of the tourist guides deliver the information to the tour passengers. Therefore researcher also used to record some information that was supposed to be relevant data.

Since the data of this study is qualitative data, the researcher applied four phases of analytical process based on Dörnyei's theory (2007: 246) such as (a) transcribing the data, (b) pre-coding and coding, (c) interpreting the data and drawing conclusion. Transcribing the Data as Dörnyei (2007: 246) states that the first step in data analysis is to transform the recordings into textual form. According to Dörnyei the only good thing to say about the transcription process is that it allows us to get to know our data thoroughly, otherwise it is usually a far-to-long and less-than-enjoyable process

In this study, the transcription was conducted in two ways. Transcription was prepared in couple hours after audio records data were collected. It was applied to alleviate error of listening the records and to avoid the damage of audio records. This is what so called precoding reflection. Pre-coding reflections that may involve reading and reading transcription, reflecting on them, and noting down our thoughts in journal entries and memos shape our thinking about the data and influence the way we will go about coding (Dörnyei, 2007: 250). 
The final phase of the data analytical process in this study is interpreting the data and drawing conclusion. Actually, the researcher accomplished the process of data interpretation not only near the end of the study, but also tentatively interpreting as early as the initial coding stage when the researcher prepared the memo.

Through this study, the researcher analyzed the identification of self-presentation, communication strategies and professionalism data analysis. The aim is to identify how far the Tourist Guides that in charge of the guided tour cruise ship passenger at Lembar harbor are representatives in terms of interfacing between a tourism destination and its visitors, and Tourist Guides are very much responsible for the overall impression and satisfaction offered by a destination, and to prove whether they become Tourist Guides Professionalism or not and how do they go about creating impressions of themselves.

\section{RESEARCH FINDINGS AND DISCUSSION Research Findings}

The results data about about communication strategies used by the tour guide shows the five categories taxonomy of impression management techniques on tourist guides professionalism in Lombok, especially for five tourist guides based on five tour packages being offered by the cruise director as the subjects of the study. Leary, (1993) and Schlenker, (2000) affirmed: "Self-presentations presumably require people to increase their claims of social desirability. Self-presentation is also known as impression management which indicates that an individual would act intentionally to regulate the impression of themselves according to different situations, in order to shape an appropriate image to gain approval from others.

There is a variety of taxonomy for self-presentation, Jones and Pittman (1982) classified self- presentation strategies into five categories, including (1). Self- promotion (2). Ingratiation (3). "Exemplification" (4). "Intimidation" and (5) "Supplication",

The result data transcription Self Presentation Strategies of the First Category "SelfPromotion": as Tourist guide 1 affirmed: "And our religion in Lombok is sound like aa like eighty five percents with Muslim religion and than the rest is Christian, Hindus...", Tourist guide 2 expressed: "It's a big event in Lombok for princess cruises ya aa totally this year I was saying twenty seven cruise ships visit Lombok ya and last year would be the same about twenty seven cruise ships Lombok is getting popular ya ahmm...we have new international airport right now and new flight from Perth to Lombok by jet star..." Tourist guide 3 expressed: "Because as we know that Lombok island divided into four a regional ya district and one administrative.. so the regional is West Lombok with the capital of Gerung and then Central Lombok with the capital of se aa Praya East Lombok with the capital of Selong and then North Lombok with the capital of Tanjung so the administrative is Mataram..so Mataram also as the capital town of West Nusa Tenggara Province.." Tourist guide 4 expressed: "And Lombok itself means chili ladies and gentleman. Lombok means chili.. if you see that here aa Lombok's size is quite similar as Bali size with regard from east to the west is ninety kilometers and aa from south to the north one hundred and ten kilometers length so it's quite similar like Bali and the population on Lombok is three millions five hundred thousand which is quite lot actually..." Tourist guide 5 expressed "In Lombok we don't have industry, no textile no factory the process of everything done by hand with traditional system for example like farming system. In Lombok when we grow plantation we grow rice and everything mostly we are not much use chemical fertilizer mostly use 
organic fertilizer we make compost compost is organic to keep the land fertilize we use traditional system..."

Based on the result data transcription of Self Presentation Strategies for Ingratiation Category such as Tourist guide 1 expressed: "So ladies and gentleman we,ll be visiting some of interesting places in Lombok so before we are going to visit one of the place, I would like to refreshing of your mind, and to give you information little bit of Lombok, little bit of Lombok..(may be not little bit but more that little bit..ha ha ha... make a lot". Tourist guide 2 expressed: "So like our tour handicraft or craft village so you'll shop ya, (I will tell you a word that might help you to shop, do you know Tajmahal..yes.. just remember one word mahal..mahal..that's mean .. Expensive..ha ha ha..mahal.. ya.." Tourist guide 3 expressed: "And then around fifty years ago ya fifty years ago in Lombok island famous with the big of families...ya because in one family ya at that time also in Lombok island we find a lot of football team ha ha yes many football team in Lombok island because in one family they have children until twelve...twelve children so one family can make one football team in Lombok island..ha ha ha ha.." Tourist guide 4 expressed: "As you see on the road the cidomo the horse cart the horses are small the horses are small yes they look like pony but they are very strong you see and then they take it as the transportation from market normally to the house so that's why we called it Lombok Taxi...(for short distance ya ladies and gentleman not more than five kilometers otherwise your horse will go to hospital ha ha ha ha ...."Tourist guide 5 expressed "So we have small in Lombok only ninety by ninety kilometers we have total population about three point two million inhabitant.... quite busy ya...three point two... million many people here ha ha ha ya so many making baby ya ha ha.."

The result data transcription of Self Presentation Strategies for Exemplification Category such as: Tourist guide 1 expressed: "This temple is full of steps, so you must be careful when you walk down or you walk up to the step... And the thing you have to know in here because is like so many hawkers who selling the staff in here and then if you interesting with something if you wanna buy so you can buy but don't touch ok don't asking about the price because in here is different like when you say when is aa when when you asking the normal price that mean you have to buy...ya ..if interesting you can ask the price and you have to bargain..." Tourist guide 4 expressed: "The place that I highlighted where you are going to...for aa stops ..for places to visit..here you are sir map...' Tourist guide 5 expressed "Art market that many many shop you looking around na if you interesting and got signal to buy you must bargaining..."

Based on The result data transcription of Self Presentation Strategies for Intimidation Category such as: Tourist guide 1 expressed: "So welcome to the art market ... So we are here around... is like we are here around half an hour...half an hour ya.....its Lombok time now is like nine thirty seven, so we are here like half an hour..." Tourist guide 2 expressed: "So remember that our bus is purple number one..ya..purple number one we suppose to be here back from the tour at twelve thirty ...so about four hours" Tourist guide 4 expressed: "We have here thirty minutes ladies and gentleman ... thirty minutes...thirty minutes yes thirty minutes..." as final point, the result data transcription of Self Presentation Strategies for Supplication Category such as: Tourist guide 3 expressed: "And then I'm so sorry when I make mistake may be in my language and my joke ya.. so very sorry ya..."

\section{Discussion}


The research question inquired: "What are the communication strategies used by types of the tourist guides? The results confirm taxonomy for communication strategies strategies, There were five categories, including self-promotion, Ingratiation, supplication, exemplification and Intimidation. Self-presentation strategies which are employed by individuals to manage impressions formed of them by audiences and are used as a coding strategy within this study.

Table. 1

Communication Strategies

\begin{tabular}{ll}
\hline Tour Guide & Communication Strategy Used \\
\hline 1th & "And our religion in Lombok is sound like a.. a like eighty five percents \\
& with moslem religion and than the rest is christian, hindus..." \\
\hline 2nd & "ya ahmm...we have new international airport right now and new flight \\
& from perth to lombok by jet star..." \\
\hline 3th & "we know that Lombok island divided into four a regional ya distric and \\
& "Lombok idministrative.." \\
\hline 4th & "In Lombok we don't have industry, no textile no factory the proces of \\
\hline th & everything done by hand with traditional system"
\end{tabular}

There are two types of communication performed by the tourist guides in Lombok namely: (1). "Self-promotion" is designed to impress an audience with one's competence. It includes self-enhancement and specific self-praise (2). "Self Ingratiation" is designed to draw liking from the audience; it has been differentiated into a variety of specific behaviors such as humor and smiling. And based on research result in chapter four, Tourist guide 1 performed selfpromotion (he expresses : "And our religion in Lombok is sound like aa like eighty-five percents with Muslim religion and than the rest is Christian, Hindus...") self- Ingratiation (he expresses : "May be not little bit but more that little bit..ha ha ha... make a lot") selfIntimidation...( he expresses : so we are here around... is like we are here around half an hour...half an hour ya.....its lombok time now is like nine thirty seven, so we are here like half an hour...) Self- Exemplification (This temple is full of steps, so you must be careful when you walk down or you walk up to the step) (And the thing you have to know in here because is like so many hawkers who selling the staff in here and then if you interesting with something if you wanna buy so you can buy but don't touch ok don't asking about the price because in here is different like when you say when is aa when when you asking the normal price that mean you have to buy...ya ..if interesting you can ask the price and you have to bargain...)

Tourist guide 2 performed self- promotion (he expresses : (It's a big event in Lombok for princess cruisess ya aa totally this year I was saying twenty seven cruise ships visit Lombok ya and last year would be the same about twenty seven cruise ships Lombok is getting popular ya ahmm...we have new international airport right now and new flight from Perth to Lombok by jet star...) self- Ingratiation (he expresses : So like our tour handycraft or craft village so you'll shop ya, (I will tell you a word that maight help you to shop, do you know Tajmahal..yes.. just remeber one word mahal..mahal..that's mean .. expensive..ha ha ha..mahal.. ya..) Self-Intimidation (So remember that our bus is purple number one..ya..purple number one we supose to be here back from the tour at twelve thirty ...so about four hours) Tourist guide 3 Rana Widi performed self- promotion (he expresses : (Because as we know that Lombok island divided into four a regional ya distric and one administrative.. so the regional is West Lombok with the capital of Gerung and then Central Lombok with the capital of se aa Praya East Lombok with the capital of Selong and then North lombok with the capital of Tanjung so the administrative is Mataram..So Mataram also 
as the capital town of West Nusa tenggara Province..) Self - Ingratiation (And then around fifty years ago ya fifty years ago in Lombok island famous with the big of families...ya because in one family ya at that time also in Lombok island we find a lot of football team ha ha yes many footbal team in Lombok island because in one family they have children until twelve...twelve children so one family can make one football team in Lombok island..ha ha ha ha..) Self-Supplication (And then I,m so sorry when I make mistake may be in my languange and my joke ya.. so very sorry ya...) Tourist guide 4 performed self-promotion (he expresses : And Lombok itself' means chili ladies and gentleman..Lombok means chili.. if you see that here aa Lombok's size is quite similar as Bali size with regard from east to the west is ninty kilometers and a from to the north one hundred and ten kilometers length so it's quite similarlike Bali and the populationon Lombok is three millions five hundred thousand which is quite lot actually...) Self-Ingratiation Guide 4 As you see on the road the cidomo the horse cart the horses are small the horses are small yes they look like pony but they are very strong you see and then they take it as the transportation from market normally to the house so that's why we called it Lombok Taxi...(for short distance ya ladies and gentleman not more than five kilomenters otherwise your horse will go to hospital ha ha ha ha ....) Self-Intimidation (We have here thirty minutes ladies and gentleman ... thirty minutes...thirty minutes yes thirty minutes...) Self-Exemplification (The place that I highlighted where you are going to...for aa stops ..for places to visit..here you are sir map...)

Tourist guide 5 performed self-promotion (he expresses In Lombok we don't have industry, no textile no factory the proces of everything done by hand with traditional system for example like farming system In Lombok when we grow plantation we grow rice and everything mostly we are not much use chemical fertilizer mostly use organic fertilizer we make compost compost is organic to keep the land fertilize we use traditional system...) SelfIngratiation So we have small in Lombok only ninety by ninety kilometers we have total population about three point two million inhabitant..(quite busy ya...three point two... million many people here ha ha ha ya so many making baby ya ha ha.) Self-Exemplification (Artmarket that many many shop you looking around na if you intersting and got signal to buy you must bargaining...)

By applying those communication strategies, the tourist guides were trying to gain some goals. The first goal is for self-promotion which surely affected comfortable feeling of the visitors. The broader goal is to get destination promotion which surely affected the sustainablility of the tourism objects being visited.

\section{CONCLUSION}

To sum up, the communication strategies used by the tourist guides affected many dimentions of tourism. However, those communication strategies were shortly can be concluded into the following conclusions:

a. The tourist guide 1 emphasized his expression such as "And our religion in Lombok is sound like a..a like eighty five percents with moslem religion and than the rest is christian, hindus..."

b. The self- promotion was performed by tourist guide 2 made clear his expression: "It's a big event in Lombok for princess cruisess ya aa totally this year I was saying twenty seven cruise ship visit Lombok ya and last year would be the same about twenty seven cruise ship Lombok is getting popular ... ya ahmm...we have new international airport right now and new flight from perth to lombok by jet star..."

c. The self- promotion was performed by the tourist guide 3 made an impression: "Because as we know that Lombok island divided into four a regional ya distric and one administrative.. so the regional is West Lombok with the capital of Gerung and then 
Central Lombok with the capital of Praya, East Lombok with the capital of selong and then North lombok with the capital of Tanjung so the administrative is Mataram..so Mataram also as the capital town of West Nusa tenggara Province ..."

d. And tourist guide 4 performed self promotion of his expression such as: "And Lombok itself means chili ladies and gentleman..Lombok means chili.. if you see that here aa Lombok's size is quite similar as Bali size with regard from east to the west is ninty kilometers and aa from south to the north one hundred and ten kilometers length so it's quite similarlike Bali and the populationon Lombok is three millions five hundred thousand which is quite lot actually..."

e. Then, tourist guide 5 presented self promotion on his expression: "In Lombok we don't have industry, no textile no factory the proces of everything done by hand with traditional system for example like farming system In Lombok when we grow plantation we grow rice and everything mostly we are not much use chemical fertilizer mostly use organic fertilizerwe make compost compost is organic to keep the land fertilize we use traditional system..."

\section{REFERENCES}

Baker, W.E. and Sinkula, J.M. (2010): The Synergistic Effect of Market Orientation and Learning Orientation on Organizational Performance, Journal of the Academy of Marketing Science. 27 (4), 411-427.

Baker, W.E. and Sinkula, J.M. (2005): Market Orientation and the New Product Paradox, Journal of Product Innovation Management, 22 (6), 483-502.

Baker \& Sinkula (2007). Market Orientation and the New Product Paradox, Journal of Product Innovation Management, 27 (4), 411-427.

Barker, A. (2010) Improve your communication skills Rev. 2nd ed. London. Replika Press Pvt Ltd

Dörnyei, Zoltán. (2007) Research Methods in Applied Linguistics. Oxford: Oxford University Press.

Felson, R. B. (2008): An Interactionist Approach to Aggression, in: Tedeschi, James T. (Ed.), Impression Management Theory and Social Psychological Research Academic Press, New York.

Goffman, E., (2005) The Presentation Of Self In Everyday Life . Doubleday anchor books by Doubleday and company Garden City New York.

Hamilton, N. W. (2001). Academic Tradition and the Principles of Professional Conduct. Journal of College and University Law, 27(3): 609-67.

Jones, E. E., and Pittman, T. S. (2002). Toward a general theory of strategic selfpresentation. In J. Suls (Ed.), Psychological perspectives on the self (Vol. 1, pp. 231-262). Hillsdale, NJ: Lawrence Erlbaum Associates

Pond, K. (1993) The professional guide: Dynamics of tour guiding, New York. Newyork Press.

Van Nostrand Reinhold. Reisinger,and Steiner,(2006)"Reconceptualising interpretation: the role of tour guides in authentic tourism", Current Issues in Tourism, Vol.9, No.6, pp. 481-498. Quiroga.

Rabotić, B.; (2009). The Creative Role of Tourist Guiding;Proceedings of the International Tourism Conference"Cities as Creative Spaces for Cultural Tourism" (CD format); Istanbul. Press

Schlenker, B. R. (2000). Impression management. In Encyclopedia of psychology (Vol. 4, pp. 236-237). New York, NY: Oxford University Press.

Schlenker, B. R. (2008). Impression management: The self-concept, social identity, and interpersonal relationships. Monterey, CA: Brooks/Cole. 
Schlenker. (2008) Audiences' reactions to self-enhancing, self-denigrating, and accurate self- presentations. Journal of experimental social psychology

Schlenker, B. R., \& Pontari, B. A. (2000). The strategic control of information: Impression management and self-presentation in daily life. In A. Tesser, R. Felson, \& J. Suls (Eds.), Perspectives on self and identity (pp.199-232). Washington, DC: American Psychological Association. 